\title{
The "S" in ESG and international labour standards
}

\author{
Bernd Waas ${ }^{1}[$ \\ Received: 10 February 2021 / Accepted: 30 March 2021 / Published online: 13 April 2021 \\ (c) The Author(s) 2021
}

\begin{abstract}
The paper examines the importance of international labour standards for ESG reporting.
\end{abstract}

Keywords ESG $\cdot$ International labour standards $\cdot$ ILO

\section{Introduction}

Environmental, Social, and Corporate Governance (ESG) refers to the three central factors in measuring the sustainability and societal impact of an investment in a company. The topic is anything but new, but has recently gained significant momentum. This is due not least to the trend toward basing investment decisions more strongly on ethical guidelines and sustainability. As a result, investment analysis is now more focused on ESG criteria than ever before. In an effort to more accurately capture the position on ESG, various ESG rating systems have emerged. There is no shortage of standards, indeed there is rather a certain abundance. ${ }^{1}$ ESG rating systems rank companies based on ESG criteria and assess their performance on a sustainability scale. However, this is a tricky task. The difficulties that arise have numerous causes. One is the sheer breadth of issues to be addressed. Another is the fact that it is extremely challenging to define objective criteria for the performance of companies (and even more difficult to measure it). This is particularly true for social criteria, which at the same time seem to be coming more and more into focus. There seems to be some consensus that many of the issues addressed by the criterion revolve around the observance of international human

Bernd Waas is a member of the Committee of Experts on the Application of Conventions and Recommendations (CEACR) of the ILO.

\section{Bernd Waas}

1 Chair of Labour Law and Civil Law, Institute of Civil and Commercial Law, Faculty of Law, Goethe University Frankfurt, Campus Westend, RuW, Theodor-W.-Adorno-Platz 4, 60629 Frankfurt am Main, Germany rights, with the rights of workers playing an essential role. However, there seems to be less clarity about what specific requirements should follow from this.

This paper aims to contribute to the discussion by taking a closer look at the social responsibility of companies towards workers. Based on the assumption that social standards on the one hand and the protection of workers' rights under international law on the other hand are closely interrelated, the international framework will be presented first (II.). This framework consists to a large extent of the so-called International Labour Standards (ILS), i.e. the legal instruments elaborated within the International Labour Organisation (ILO) that lay down fundamental principles and rights at work. Next, some of the standards that exist in the social domain are presented (III.). Due to their widespread use and practical importance, standards of the Global Reporting Initiative (GRI) have been selected as examples, namely those that relate to collective labour law issues. These standards are then discussed in more detail against the background of the existing international legal framework in this regard (IV.). The paper ends with a short conclusion (V.).

\section{The international legal framework}

\section{The International labour organisation}

The International Labour Organisation (ILO) is a specialised agency of the United Nations. Its headquarters are in Geneva. The ILO owes its existence to the Treaty of Versailles. Its Constitution forms Part XIII of that Treaty. The basic purpose of the ILO is set out in the Preamble to the Constitution. Its

\footnotetext{
${ }^{1}$ See the Economist, Oct 3rd 2020: "In the soup-The proliferation of sustainability accounting standards comes with costs".
} 
first sentence reads: "World peace can be built in the long run only on social justice". A certain reorientation of the ILO's objectives then took place, under the impression of World War II, with the Philadelphia Declaration of 1944, whose much-quoted first principle reads: "Labour is not a commodity". The ILO Declaration on Fundamental Principles and Rights at Work, adopted in 1998, underlines the importance of the so-called core labour standards and recognises them as universal human rights in that "all Members, even if they have not ratified the Conventions in question, have an obligation arising from the very fact of membership in the Organization, to respect, to promote and to realize, in good faith and in accordance with the Constitution, the principles concerning the fundamental rights which are the subject of those Conventions". With the Decent Work Agenda of 1999, the ILO focused its work on four strategic objectives, the first being the implementation of core labour standards. The socalled ILO Declaration on Social Justice for a Fair Globalization, adopted in 2008, specifies the ILO's goals and takes into account the particular challenges of globalisation.

The main task of the ILO is to formulate and enforce international labour standards. The special feature of the organisation, apart from this specific purpose, lies in its tripartite organisation. According to Art. 1(2) of the Constitution of the ILO, members of the ILO are the states that were members of the organisation on 1 November 1945 and all other states that joined later. However, within the ILO, workers' and employers' representatives participate on an equal footing. This applies first of all to the work of the International Labour Conference (ILC), the highest organ of the ILO, which meets once a year in Geneva. Each member state has four delegates in the ILC, two of whom are government representatives, while workers' and employers'organisations each have one delegate. ${ }^{2}$ The primary task of the ILC is to formulate legal acts. The Governing Body is the executive body of the ILO and is composed of 56 representatives (28 government representatives, 14 representatives each from the social partners). ${ }^{3}$ This body also appoints the Director General. ${ }^{4}$ The International Labour Office acts as the permanent secretariat of the ILO. ${ }^{5}$

\section{International labour standards}

\section{ILO conventions and recommendations}

ILO standards are divided into conventions and recommendations: Recommendations are not open to ratification, but give guidance as to policy, legislation and practice.

\footnotetext{
2 Art. 3(1) of the Constitution.

${ }^{3}$ Art. 7(1) of the Constitution.

${ }^{4}$ Art. 8(1) of the Constitution.

5 Art. 10 of the Constitution.
}

Conventions have legal effect after ratification by a member state. There are currently 190 Conventions in force. Eight conventions stand out because of their fundamental importance: Convention No. 29 on Forced Labour; Convention No. 87 on Freedom of Association and Protection of the Right to Organise, 1948; Convention No. 98 on the Right to Organise and to Bargain Collectively, 1949; Convention No. 100 on Equal Remuneration, 1951; Convention No. 105 on the Abolition of Forced Labour, 1957; Convention No. 138 on Minimum Age, 1973; Convention No. 182 on Worst Forms of Child Labour, 1999; and Convention No. 111 on Discrimination (Employment and Occupation), 1958. In addition to these so-called fundamental conventions, there are four so-called governance conventions. Convention No. 81 on Labour Inspection in Industry and Commerce of 1947, in particular, is one of them. The remainder of the Conventions is currently made up of the so-called technical conventions.

In addition to these standards, other ILO activities are also relevant in the present context. Particular mention should be made of the Tripartite declaration of principles concerning multinational enterprises and social policy (MNE Declaration) which provides direct guidance to enterprises on social policy and inclusive, responsible and sustainable workplace practices and addresses multinational enterprises, governments and employers' and workers' organisations. This instrument was elaborated and adopted by governments, employers and workers from around the world. It is firmly rooted in principles contained in international labour standards, ${ }^{6}$ and on obligations that States have through their ILO membership and following their ratification of ILO Conventions.

\section{Monitoring of standards}

With regard to the monitoring of compliance with ILO standards by the member states, there is a sophisticated and it must be said relatively complicated mechanism involving various actors. It will not be discussed in detail here, since a few basic facts should suffice in the present context.

The Committee on Freedom of Association (CFA) is responsible for complaints about alleged violations of freedom of association. To date, the Committee has issued opinions on approximately 3,200 cases. The Committee has a tripartite structure. The Chairman of the Committee is independent. In addition to this and some other specific mechanisms, there is regular machinery for supervising the observance of obligations deriving from Conventions and Recommendations. Here, monitoring is based on reports which the members of the ILO have to submit at regular

\footnotetext{
${ }^{6}$ See the ILO conventions and recommendations listed in Annex I of the instrument.
} 
intervals. ${ }^{7}$ It is important to note that the Member States are obliged to communicate their reports to the representative organisations of employers and employees in their country. ${ }^{8}$ Where observations from those organisations on the application of ratified Conventions are received by a government, full details should be sent in the government's report, together with the government's response, if any. ${ }^{9}$ Regular supervision of standards is carried out, on the one hand, by the Committee of Experts on the Application of Conventions and Recommendations (CEACR) ${ }^{10}$ and, on the other, by the Conference Committee on the Application of Standards (CAS). The Committee of Experts consists of independent experts. Its task is to provide an exclusively legal assessment on the basis of reports of Governments (and observations of the representative organisations of employers and employees from the relevant country). It is then task of the CAS to consider individual cases relating to the application of ratified Conventions. These cases, however, are selected and treated on the basis of the findings of the Committee of Experts. ${ }^{11}$

It is clear from the above that the reports of the Committee of Experts are of paramount importance for understanding ILO standards. This is true despite the fact that the Committee-unlike, for example, the European Court of Human Rights, which monitors compliance with the European Convention on Human Rights-is not a court and that its observations are not legally binding. And this is also true despite the fact that the mandate of the Committee is not undisputed among the constituents of the ILO, a dispute that is only superficially about the international legal guarantee of the right to strike (which the Committee affirms), but which might go deeper. ${ }^{12}$ This is because the core of the mandate, namely that within the standards monitoring

\footnotetext{
7 Art. 22(1) of the Constitution.

8 Art. 22(2) of the Constitution.

9 Employers' and workers' organizations may also send observations directly to the Office. See ILO, Handbook of procedures relating to international labour Conventions and Recommendations, Centenary Edition 2019, para. 40.

${ }^{10}$ See ILO (footnote 9), para. 60: “The Committee's fundamental principles are those of independence, impartiality and objectivity in noting the extent to which the position in each State appears to conform to the terms of the Conventions and the obligations accepted under the ILO Constitution".

11 See ILO (footnote 9), para 66: "Following the independent, technical examination of documentation carried out by the Committee of Experts, the proceedings of the Conference Committee present an opportunity for representatives of governments, employers and workers to meet and review the manner in which States are discharging their obligations under and relating to Conventions and Recommendations. Governments are able to amplify information previously supplied; indicate further measures proposed; draw attention to difficulties met with in the discharge of obligations; and seek guidance as to how to overcome such difficulties".

12 See, for instance, La Hovary, A Challenging Ménage à Trois? Tripartism in the International Labour Organization, International Organizations Law Review, 122015 pp. 204-236.
}

system the Committee of Experts alone is called upon to legally assess the law and practice of the Member States, is not in dispute among the parties involved. Quite apart from this, another point is of importance in the present context, namely that the observations of the Committee of Experts have been taken up by numerous national ${ }^{13}$ and also by international courts ${ }^{14}$ in questions of legal interpretation, which shows that they carry great weight, even if they are not legally binding as such. ${ }^{15}$

\section{GRI social standards}

As already mentioned in the introduction, only a fraction of the existing social standards can be discussed here. Instead, only the standards of the Global Reporting Initiative will be examined, and only those that address issues of collective labour law. These standards can be found in the Consolidated Set of GRI Sustainability Reporting Standards 2020. ${ }^{16}$ Generally speaking, there are two types of standards: On the one hand, the so-called universal standards that apply to every organisation preparing a sustainability report and which aim primarily at contextual information about an organization (GRI 102) as well as the management approach for each material topic (GRI 103), and on the other hand the so-called topic-specific standards. With regard to the latter, a distinction is made between three areas, so that there are economic, environmental and social standards. Obviously, it is the latter set of standards that are the focus of interest here.

\footnotetext{
${ }^{13}$ From the Supreme Court of Canada, for example, or the Constitutional Court of South Africa.

${ }^{14}$ Particularly noteworthy in this respect is the European Court of Human Rights, which in its decisions relatively often refers to findings of the CEACR (and of those of the CFA).

15 See also the description of its mandate by the Committee itself in the Report of the Committee of Experts on the Application of Conventions and Recommendations, International Labour Conference, 109th Session 2020, para 36: “(...) The Committee of Experts undertakes an impartial and technical analysis of how the Conventions are applied in law and practice by member States, while cognizant of different national realities and legal systems. In doing so, it must determine the legal scope, content and meaning of the provisions of the Conventions. Its opinions and recommendations are nonbinding, being intended to guide the actions of national authorities. They derive their persuasive value from the legitimacy and rationality of the Committee's work based on its impartiality, experience and expertise. The Committee's technical role and moral authority is well recognized, particularly as it has been engaged in its supervisory task for more than 90 years, by virtue of its composition, independence and its working methods built on continuing dialogue with governments taking into account information provided by employers' and workers' organizations. This has been reflected in the incorporation of the Committee's opinions and recommendations in national legislation, international instruments and court decisions".

16 https://www.globalreporting.org.
} 


\section{Overview of existing standards}

The social standards contain quite a few criteria that aim at the position of workers. The following standards are worth mentioning: 401, which deals with "employment"17; GRI 402 on "labour-management relations"; GRI 403 on "occupational health and safety"; GRI 404 on "training and education"; GRI 405 on "diversity and equal opportunity"; 406 on "non-discrimination"; GRI 407 on "freedom of association and collective bargaining"; GRI 408 on "child labor", 409 on "forced or compulsory labor". A few standards somehow relate to the position of staff. This applies to GRI 410 on "security practices"; GRI 411 on the "rights of indigenous people "; GRI 412 on "human rights assessment", and, finally, GRI 414 on "supplier social assessment".

All these standards are, in a sense, two-part. Firstly, there is, in general terms, the obligation to report on how an organization manages a certain issue. What is required in this respect is "a narrative explanation of how an organization manages a material topic, the associated impacts, and stakeholders' reasonable expectations and interests". ${ }^{18}$ These so-called management approach disclosures are then joined by so-called topic-specific disclosures. Most of the standards mentioned are presented after an introduction. Moreover, so-called reporting requirements ${ }^{19}$ and so-called reporting recommendations ${ }^{20}$ as well as short guidance notes ${ }^{21}$ are formulated for each standard or each subgroup of standards. Each standard is then followed by a glossary and a list of references.

\section{A closer look at GRI 402 and 407}

A serious evaluation of the GRI standards from the perspective of international labour law would obviously require a

\footnotetext{
17 In the so-called background context which forms part of the "Introduction" to the standard, it is explained that GRI 401 "addresses the topic of employment" which "includes an organization's approach to employment or job creation, that is, an organizations approach to hiring, recruitment, retention and related practices, and the working conditions it provides". It is further explained that the standard "also covers the employment and working conditions in an organization's supply chain".

18 Details can be found in GRI 103.

19 These are „mandatory instructions”. Requirements “are to be read in the context of recommendations and guidance; however, an organization is not required to comply with recommendations or guidance in order to claim that a report has been prepared in accordance with the Standards".

${ }^{20}$ Recommendations relate to "cases where a particular course of action is encouraged, but not required".

${ }^{21}$ The relevant sections "include background information, explanations and examples to help organizations better understand the requirements".
}

more detailed examination. However, this cannot be done here for all standards related to the position of workers. Instead, GRI 402 on "labour-management relations" and GRI 407 on "freedom of association and collective bargaining" will be discussed here by way of example, as they deal with highly significant issues, also in practical terms, and are closely interrelated, as will be shown in a moment.

\section{Management approach disclosures}

As already mentioned, all GRI standards first require information on the management approach that companies pursue with regard to certain problem areas. This also applies to GRI 402-1 and 407-1. The benchmarks for this are derived from the general standard GRI 103. Without being able to go into detail here, the companies must provide information on the extent to which they come into contact with a certain topic through their actions or what effects their actions have in these areas (GRI 103-1). More importantly, they must provide information on their specific management approach. This requires, above all, information on policies commitments, goals and targets, responsibilities, resources; grievance mechanisms, and specific actions, such as processes, projects, programs and initiatives (GRI 103-2 lit. c). Finally, the company must provide an explanation of how the organization evaluates its management approach, including: the mechanisms for evaluating the effectiveness of the management approach; the results of the evaluation of the management approach; and any related adjustments to the management approach. (GRI 102-3). According to the relevant guidance note, mechanisms for monitoring the effectiveness of the management approach can include: internal or external auditing or verification (type, system, scope); measurement systems; external performance ratings; benchmarking; stakeholder feedback; and grievance mechanisms.

\section{Topic-specific disclosures}

GRI 402 contains only one sub-standard. GRI $402-1$ on "disclosure" requires the reporting organisation to "report the following information: a. Minimum number of weeks' notice typically provided to employees and their representatives prior to the implementation of significant operational changes that could substantially affect them. b. For organisations with collective bargaining agreements, report whether the notice period and provisions for consultation and negotiation are specified in collective agreement". The "background context" which forms part of the introduction reads as follows: "GRI 402 addresses the topic of labor/ management relations. This covers an organisation's consultative practices with employees and their representatives, including its approach to communicating significant operational changes. An organisation's consultation practices are 
expected to be aligned with relevant international norms and standards. Collective bargaining can play an important role in an organisation's consultation practices. Collective bargaining refers to all negotiations which take place between one or more employers or employers' organisations, on the one hand, and one or more workers' organizations (trade unions), on the other, for determining working conditions and terms of employment or for regulating relations between employers and workers".

GRI 407 on "freedom of association and collective bargaining" also contains only one substandard. Under Standard 407-1 "the reporting organisation shall report the following information: a. Operations and suppliers in which workers' rights to exercise freedom of association or collective bargaining may be violated or at significant risk either in terms of: i. type of operation (such as manufacturing plant) and supplier; ii. countries or geographic areas with operations and suppliers considered at risk. b. Measures taken by the organization in the reporting period intended to support rights to exercise freedom of association and collective bargaining". In the Guidance it is further explained that this " disclosure concerns an organization's due diligence with respect to any adverse impacts its activities have had on the human rights of workers to form or join trade unions and to bargain collectively. This can include policies and processes with respect to the organization's business relationships, including its suppliers. It can also include the due diligence process to identify operations and suppliers where these rights are at risk. It also aims to reveal actions that have been taken to support these rights across an organization's range of operations. This disclosure does not require the organization to express a specific opinion on the quality of national legal systems". As far as collective agreements are concerned, it is further explained that these "can be at the level of the organization; at the industry level, in countries where that is the practice; or at both". In this context, the Guidance further reads: "Collective agreements can cover specific groups of workers; for example, those performing a specific activity or working at a specific location. An organization is expected to respect the rights of workers to exercise freedom of association and collective bargaining. It is also expected to not benefit from or contribute to such violations through its business relationships (e.g. suppliers)".

\section{Importance of standards and their inter-relatedness}

The relevance of these two standards is primarily due to the paramount importance of freedom of association and collective bargaining for the protection of workers: As the individual workers are typically the weaker party, it is precisely the possibility of forming or joining trade unions and thus of building countervailing power as guaranteed by freedom of association, that opens up the prospect of concluding collective agreements, which in turn are far more likely than the individual employment contract to lead to fair working conditions. Whereas GRI 407 directly addresses these issues, GRI 402 relates to them insofar as-with regard to the possibility of having a say in significant operational changes - it refers on the one hand to corresponding provisions in collective agreements (GRI 407-1 lit. b) and on the other (GRI 407-1 lit. a) to the obligation to notify employee representatives (or the employees directly). With regard to the involvement of "representatives", the connection to freedom of association then follows from the fact that these representatives can only be "trade union representatives" unless they are, which is also possible, employee representatives elected directly by the workforce (e.g. works councils). If one considers all this, it also becomes clear that both standards are closely connected. At the same time, they are the only standards that deal exclusively (GRI 407) or at least predominantly (GRI 402) with issues that labour lawyers classify as belonging to collective labour law.

\section{Evaluation of standards}

\section{Some general observations}

\section{Link with international labour standards}

Looking at the GRI standards mentioned above as a whole, it is noticeable that they are linked to a large extent to international labour standards. This is the case, for example, with GRI 401 on "employment". There, not only reference is made to "key instruments of the International Labour Organisation" in the introduction, but the list of references also contains numerous ILO Conventions. Also worth mentioning is GRI 402 on "labour-management relations" where it is explicitly set out in the relevant Glossary that the definition of "collective bargaining" is based on ILO Convention No. 154. The relevant list of reference encompasses ILO Conventions No. 87 on Freedom of Association and Protection of the Right to Organise, No. 98 on the Right to Organise and Collective Bargaining, No. 135 on "Workers' Representatives", No. 154 on Collective Bargaining and No. 158 on Termination of Employment. References to ILO Conventions can also be found in GRI 403 on "occupation health and safety", ${ }^{22}$ GRI 404 on "training and education", GRI 405 on "diversity and equal opportunity"; GRI 406 on "non-discrimination"; GRI 407 on "freedom of association and collective bargaining"; GRI 408 on "child labor", and GRI 409 on "forced or compulsory labor". In one case, there

\footnotetext{
${ }^{22}$ In this context, there are numerous references not only to ILO conventions, but also to other instruments such as the ILO code of practice on recording and notification of occupational accidents and diseases or the ILO list of occupational diseases.
} 
is also a reference to the ILO monitoring system: In relation to freedom of association, GRI 407-1 expressly refers to "the various outcomes of the ILO Supervisory bodies and the recommendations of the ILO Committee of Freedom of Association". ${ }^{23}$

\section{Importance of international labour standards}

That ESG rating systems should be linked to International Labour Standards seems almost to be obvious. There are substantive reasons for allowing the latter standards to shape the former. First and foremost, International Labour Standards express, almost by definition, a consensus on the working conditions to be observed. The fact that it is a global consensus gives International Labour Standards an advantage over standards such as the European Convention on Human Rights or the European Social Charter, whose scope is regionally limited; of course, this is not to diminish the fundamental importance of these instruments, especially from a European perspective. A comparison with the Council of Europe, within whose framework the European Convention on Human Rights as well as the European Social Charter was concluded, stresses another important feature of the ILO. This lies in the fact that it is a tripartite organization, so that not only the states, as is usually the case, but also the social partners, i.e. employers' associations and trade unions, are involved in setting standards. The consensus on standards is thus not only a consensus between governments (and parliaments), but a consensus that includes the organised representatives of employers and workers.

On the other hand, one might perhaps consider that international labour standards do not go far enough, precisely because they are based on and presuppose a global consensus. However, the fact that International Labour Standards are global does not necessarily mean that they are not ambitious. There are two main reasons why they are: First, the underlying standards are often quite challenging even from the perspective of Western industrialised countries; that being one of the reasons why even countries with developed labour law systems sometimes shy away from ratifying certain conventions or have difficulties implementing them into their national law after ratification. Irrespective of this, it should be noted that the ILO standards-which are inevitably broadly framed-are always further fleshed out by the relevant supervisory bodies. For this reason, too, the International Labour Standards must be taken seriously.

The fact that a comprehensive standards monitoring system exists within the ILO is also interesting for another reason. This is because the monitoring of compliance with

\footnotetext{
23 The relevant list of references provides a link to the statements of
} this Committee. standards necessarily implies a clarification of their content, and one that applies equally to all. In other words, the interpretation of standards is a necessary component of the monitoring of standards. This means, however, that there is a universally valid interpretation for all international standards, which can also be followed in the case of ECG criteria (and also should be followed, if one does not want to break the link between them and International Labour Standards). It is the very existence of such "case law" which is an invaluable advantage because, for example, one does not have to worry about what the protection of freedom of association means in concrete terms, but can simply follow the relevant findings of the ILO supervisory bodies in clarifying this question.

\section{Range and depth of international labour standards}

If, however, one considers International Labour Standards to be significant in the present context, then one should also take them seriously. International Labour Standards now cover (almost) the entire range of issues that arise with regard to the protection of workers. However, not all of the issues regulated in the corresponding ILO Conventions are reflected in the GRI Standards. This applies, to name just a few examples, to rights to time off, protection of workers' pay claims, sickness pay, numerous questions of atypical employment or the protection of special groups of workers. There is also an extensive gap in the protection against dismissal, which is particularly painful in view of its fundamental importance for the overall protection of workers.

In addition, it is important to realise that many international legal guarantees are much more rich in substance (as well as complex) than one may perhaps think at first glance. Freedom of association is a good example. In reality, it contains a whole range of guarantees, from the freedom of individuals to form and join trade unions to the freedom of associations to organise their own affairs and their right to collective bargaining. A closer look at these contents can also help to weed out issues that are not relevant in the present context. For example, it is obvious that freedom of association is to a large extent directed exclusively at the state (which, for example, must provide a legal framework for the conclusion of collective agreements), while, vis-àvis employers, freedom of association primarily contains a prohibition of obstruction and discrimination.

\section{Specific considerations}

\section{Management approach disclosures}

As already stated above, under the GRI standards each company needs to provide information on its management approach to a particular issue. Undoubtedly, the relevant information can be extremely useful precisely because it is 
capable of providing interested parties with a more comprehensive picture of how a company approaches a particular issue. Answering the question of what the "corporate philosophy" is on a particular issue is certainly of great value. However, there is always the danger that reports contain too little tangible information. In must be added in this regard that much of the information to be provided is future-oriented: it is not least about "policies", "commitments" and "goals and targets". In addition, it is noteworthy that while there are references to "international standards," once in terms of policies and once in terms of commitments, these are only recommendations and not requirements. Though it remains true that general information is certainly useful, the question arises whether the relevant general duties are usefully supplemented by more specific information duties. This draws attention to the topic-specific disclosures.

\section{Topic-specific disclosures}

If one examines GRI 402-1 in more detail, a number of questions arise: This is already the case when reading the text of the standard itself. For example, it is unclear why only GRI 402-1 lit lit. a) refers to minimum notice periods for significant operational changes, whereas GRI 402-1 lit. b) takes a much broader view by also asking whether collective agreements contain "provisions for consultation and negotiation". Moreover, GRI 402-1 lit. b) does not seem to take into account that there are also agreements not qualifying as collective agreements as employees are represented by a works council. It also seems doubtful that GRI 402-1 lit. a), taken literally, only requires information on which minimum notification periods were "typically" observed by the reporting organization, as this opens up the possibility for companies to disregard cases in their report in which significant operational changes were only communicated with very short advance notice or not at all because they were considered particularly urgent and thus "atypical". The standard thus seems to leave a considerable loophole for companies. Finally, doubts arise about the standard because GRI 4021 (a), according to its wording, measures compliance with the notice period by the "implementation" of the decision on the operational change. This seems problematic because it links the obligation to give notice to a point in time when the decision on the operational change itself has already been taken (and only its practical implementation is still pending). In that case, an obligation to give notice can scarcely be seen as serving the purpose of giving employees or their representatives an opportunity to have their say ${ }^{24}$; a circumstance that also seems hardly consistent with the fact that according to the Guidance, the standard is about the company's willingness to ensure "timely discussion of significant operational changes" and to engage "with its employees and their representatives to negotiate and implement these changes". ${ }^{25}$
GRI 402-1 also raises some questions in other respects. For example, the standard only deals with the company's obligations towards workers and their representatives. However, the guideline talks about much more than that when expressing the expectation that companies "provide reasonable notice of significant operational changes to employees and their representatives, as well as to appropriate government authorities". The importance of informing public authorities about upcoming operational changes is beyond doubt. But one should expect this to be reflected in the text of the standard itself.

GRI 407-1 also leaves room for doubts. It is obvious that the standard raises very different questions. With regard to GRI 407-1 lit. a), insofar as the standard is aimed at "operations", it seems to be concerned with identifying possible violations of freedom of association or certain risks to this in the company itself. As far as suppliers are mentioned, it is about violations/risks that can be attributed to third party companies. GRI 407-1 lit. b), however, then deals with something completely different, since the focus is not on operations or third-party companies anymore, but on "countries or geographical regions" in which freedom of association is at risk. Even more serious, however, is the fact that much of the content remains unclear: Why should a company have to report on possible violations/risks as far as its own operations are concerned? And what is meant by such possible violations/risks in the first place? It may well be that freedom of association is exposed to risks in certain countries and regions according to law and practice; a circumstance that may be derived from the opinions of the ILO monitoring bodies, to which the Guidance indeed makes explicit reference. However, it is not clear where the added value of such information should lie. In any case, an overall anti-union climate says little about "how social" a particular company is. And there should certainly be no incentives for companies to avoid countries with an antiunion environment from the outset, even if their own policies in this regard are beyond reproach. On the contrary, it seems desirable for companies with a strong social conscience to lead the way, even and especially in a thorny environment. Neither can such an environment excuse anti-union behaviour, nor can a legal framework (and practice) that is in line with applicable international guarantees absolve companies of their own obligation to respect freedom of association. Accordingly, only one question seems to make sense, namely whether a company was obliged by national regulations to

\footnotetext{
${ }^{24}$ See also the Guidance where it is indicated that minimum notice periods "ultimately serve the purpose of maintaining "employee satisfaction and motivation".

25 The Guidance also talks about ,timely and meaningful consultation".
} 
take certain anti-union measures, so that its corresponding conduct may not be held against it.

\section{Conclusion}

As already indicated, international labour standards exist for almost all working conditions. There are many reasons why ESG criteria should refer to them. At the same time, however, references to international standards could be deepened. In this way, a set of specific requirements could be developed that are missing today. This, however, would require a closer look at international labour standards. In particular, the interpretive practices of ILO supervisory bodies should be examined more closely. Going down this path promises to be beneficial for all concerned: Filling the " $\mathrm{S}$ " of the ESG criteria further with life would create more transparency and encourage companies to assume more social responsibility. It could also contribute to the enforcement of international human rights.

Funding Open Access funding enabled and organized by Projekt DEAL.

Open Access This article is licensed under a Creative Commons Attribution 4.0 International License, which permits use, sharing, adaptation, distribution and reproduction in any medium or format, as long as you give appropriate credit to the original author(s) and the source, provide a link to the Creative Commons licence, and indicate if changes were made. The images or other third party material in this article are included in the article's Creative Commons licence, unless indicated otherwise in a credit line to the material. If material is not included in the article's Creative Commons licence and your intended use is not permitted by statutory regulation or exceeds the permitted use, you will need to obtain permission directly from the copyright holder. To view a copy of this licence, visit http://creativecommons.org/licenses/by/4.0/.

\section{References}

General Reporting Initiative, GRI-Standsrds. https://www.globalrepo rting.org/standards

General Reporting Initiative, GRI-Standards. https://www.globalrepo rting.org/standards

Hovary, La. 2015. Claire, A Challenging Ménage à Trois? Tripartism in the International Labour Organization. International Organizations Law Review 12: 204-236.

ILO, Handbook of procedures relating to international labour Conventions and Recommendations, Centenary Edition 2019.

ILO, Report of the Committee of Experts on the Application of Conventions and Recommendations, International Labour Conference, 109th Session 2020.

Publisher's Note Springer Nature remains neutral with regard to jurisdictional claims in published maps and institutional affiliations. 